\author{
К. Білоус, \\ аспірант кафедри цивільного процесу \\ Національного юридичного університету імені Ярослава Мудрого
}

\title{
СПРОЩЕНЕ ПРОВАДЖЕННЯ ЯК ПРОЦЕСУАЛЬНА ФОРМА РОЗГЛЯДУ МАЛОЗНАЧНИХ СПРАВ
}

Становлення i подальша генеза спрощених форм відправлення правосуддя є органічним наслідком глобалізації цивільного судочинства та головним фактором інституціоналізації правових механізмів забезпечення доступності правосуддя на рівні національних правових порядків, що контекстуально пов'язує спрощені провадження із «третьою хвилею» всесвітнього руху «Доступність правосуддя». Поява останніх стала можливою завдяки утвердженню загальних і більш широких за своїм змістом підходів до розуміння концепту «доступності правосуддя», в основі яких лежить ідея адаптивності цивільної процесуальної форми до специфіки правової природи та характеру спірних правовідносин. Саме ці фактори $€$ визначальними для диверсифікації цивільних спорів на відповідні категоpii, процесуальні особливості розгляду кожної з яких визначаються з огляду на ціну позову, обраний позивачем спосіб захисту, складність спору, значення справи для сторін тощо.

Консультативна рада європейських суддів приділяє особливу увагу проблемі симпліфікації юрисдикційних алгоритмів відправлення правосуддя у малозначних справах. Це знайшло своє відображення у ї̈ висновках, де наголошується на тому, що процесуальні особливості розгляду і вирішення деяких категорій цивільних спорів, включаючи спрощені провадження, визначаються 3 огляду на малозначність заявлених вимог, спірний характер права і дотримання принципу розумності строків розгляду конкретної справи [1].

Рекомендація NR (81)7 Комітету міністрів Ради Європи «Про способи полегшення доступу до правосуддя» спонукає держав-членів Ради Європи на рівні національних правових систем вжити низку заходів, спрямованих на підвищення ефективності та вдосконалення правового механізму забезпечення реалізації права на суд у цивільному судочинстві шляхом скасування застарілих правових норм або позбавлених практичного значення юрисдикційних процедур 3 метою максимального скорочення темпоральних меж розгляду окремих категорій справ.

Судові установи мають бути належним чином забезпечені кваліфікованим персоналом, а також повинен існувати законодавчо регламентований механізм контролю за ходом розгляду цивільної справи, ухваленням рішення та його подальшим виконанням; симпліфікації судових проваджень, за правилами яких розглядаються малозначні та безспірні вимоги з метою забезпечення оперативного ухвалення остаточних судових рішень без надмірної формалізації, участі представника, особистих явок сторін до суду, інших додаткових обтяжень організаційного і матеріального характеру, пов'язаних із розглядом справи по суті; встановлення пропорційного співвідношення між заявленою ціною позову і судовими витратами, мінімально необхідними для розгляду і вирішення спорів 
iз незначним розміром позовних вимог у межах спрощених судових процедур [2].

Таким чином, утвердження спрощених форм відправлення правосуддя у цивільному судочинстві здійснюється в контексті диверсифікації цивільних справ на окремі категорії, порядок розгляду та вирішення яких $€$ істотно модифікованим порівняно iз загальними правилами позовного провадження. Насамперед маються на увазі спори із невеликою ціною позову, так звані малозначні чи малоцінні справи, для яких процесуальним законодавством мають бути передбачені спрощені юрисдикційні процедури, покликані убезпечити сторін спору від непомірних організаційних, темпоральних i фінансових затрат, пов'язаних із поданням позову і розглядом справи по суті.

Особливу увагу привертає п. 15 Рекомендаціï NR (81)7 Комітету міністрів Ради Європи «Про способи полегшення доступу до правосуддя», де наголошується на доцільності запровадження спрощеного порядку розгляду i вирішення малозначних справ 3 метою деформалізації, оптимізації процедури судового розгляду та встановлення процесуальних фільтрів оскарження судових рішень у цій категорії справ [2].

Отже, в основі спрощених позовних проваджень лежить концепт «процесуальної економії», який може бути реалізований лише в умовах простоти і зрозумілості судових процедур, коли вчинення процесуальних дій не буде обтяжено різного роду обмеженнями і формальностями, що дасть можливість максимально прискорити розгляд і вирішення цивільного спору по суті.

Проблема уніфікації процесуального порядку розгляду малозначних справ стала актуальною і в Європейському Союзі (далі - ЄС), особливо в контексті зростаючої потреби у виробленні єдиних правил цивільного процесу $\in C$. Формування
Європейського Економічного Співтовариства, як слушно наголошує I.O. Ізарова, сприяло розширенню економічних та інших відносин між державами-членами і зумовило певну конкуренцію між цивільними процесуальними системами цих країн.

Забезпечення ефективного режиму захисту цивільних прав своїх громадян стало одним із основних завдань і породило стійку тенденцію до свідомого та сталого зближення європейських правових систем. Об'єднання незалежних європейських держав i подальша європейська інтеграція виступили детермінантами створення та забезпечення функціонування спільного правового простору. Це зумовило потребу в гармонізації законодавства держав-членів ЄС. Так, у сфері цивільного процесу було сформовано наднаціональний механізм регулювання відносин із розгляду цивільних і комерційних справ транскордонного характеру [3, с. 74-75].

Про необхідність формування спільного правового простору, що згодом знайде своє відображення в установчих договорах ЄС, неодноразово зазначав Марсель Сторм, який ще у 1977 році на Першому Всесвітньому конгресі IAPL Towards a Justice with a human face запропонував розробити Єдиний європейський кодекс цивільного судочинства [4]. Статтю 6 Європейської конвенції про захист прав людини i основоположних свобод (далі - ЄКПЛ) Марсель Сторм вважав головним правовим підгрунтям концепту гармонізації, підкреслюючи ii фундаментальне значення для розвитку права кожної особи на судовий захист, яке є загальним, тобто таким, що відображає спільні традиційні європейські погляди на справедливе правосуддя у цивільних справах [5, с. 17].

Протягом 1987-1994 років робочою групою під керівництвом Марселя Сторма було підготовлено колективний звіт під назвою "Approximation of Judiciary Law in the European

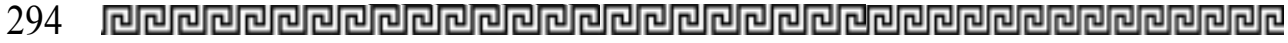


Union”, присвячений питанням уніфікації цивільного процесуального законодавства держав-членів ЄC. Хоча первісної мети (підготовки модельного цивільного процесуального кодексу) досягнуто не було, але вдалося започаткувати жваву дискусію про значення і основні вектори гармонізації національних цивільних процесів держав-членів ЄС [6, с. 153].

Каталізатором розвитку гармонізаційного процесу в ЄС стало ухвалення Амстердамського договору «Про врегулювання відносин у сфері внутрішніх справ і правосуддя» 1997 року, який сприяв усуненню перешкод на шляху нормального функціонування цивільного судочинства. Його прийняття ознаменувало початок ери застосування спільних правил цивільного процесу - перших загальноєвропейських процедур із розгляду цивільних і комерційних справ транскордонного xарактеру (European Order for Payment Procedure ma European Small Claims Procedure).

Активна законодавча діяльність Союзних інституцій, як слушно зазначає I.O. Ізарова, детермінувала появу єдиного цивільного процесу ЄС, механізм якого істотно відрізняється від конвенційної системи захисту прав, яка не змогла забезпечити необхідний рівень розвитку єдиного правового простору в умовах спільного ринку. Завдяки гармонізації цивільного процесу було запроваджено ті єдині процедури, які дозволяють уникнути проблеми диверсифікації національного регулювання цивільного судочинства [3, с. 82-83].

3 метою забезпечення узгодженості правового регулювання, оптимізаціï, пришвидшення та здешевлення процесуального порядку розгляду i вирішення малозначних спорів 11 липня 2007 року був прийнятий Регламент Європейського Парламенту та Ради Європейського союзу № 861/2007 «Про заснування європейської процедури вирішення дрібних спорів» [7], який поклав початок формуванню уніфікованої (загальноєвропейської) процедури розгляду і вирішення цивільних справ з ціною позову до $2000 €$.

Таким чином, поява спрощених форм відправлення правосуддя $є$ результатом диференціації судових процедур. Між ними існує нерозривний причинно-наслідковий зв'язок, об'єктивно зумовлений низкою глобалістичних факторів, зокрема: 1) поглибленням змістової диверсифікації цивільних справ на окремі категоріі; 2) необхідністю вироблення в межах відповідних юрисдикційних процедур індивідуального підходу до врегулювання різного роду правових конфліктів; 3) диференціацією та подальшою симпліфікацією ординарної цивільної процесуальної форми; 4) зростанням значення і поширеністю альтернативних способів розгляду цивільних справ.

У контексті зазначеного вище інституціоналізація спрощених позовних проваджень як процесуальної форми розгляду малозначних справ сприяє досягненню тих цілей і високих стандартів, які були позначені Комітетом міністрів Ради Європи у його Рекомендаціях державам-членам. Гнучкість та індивідуалізм підходів до вирішення поставлених завдань $€$ запорукою перманентного зростання рівня ефективності та оперативності судового захисту.

Наріжною тенденцією розвитку правових систем більшості демократичних країн, зокрема їх судово-правових реформ останнього часу, $€$ запровадження та правозастосовна концептуалізація спрощених форм відправлення правосуддя. Вони покликані забезпечити максимально можливу оптимізацію цивільного процесу шляхом створення умов для функціонування правового механізму розгляду і вирішення цивільної справи, який би забезпечив прийнятну оперативність у досягненні цілей і виконанні завдань цивільного судочинства. 
Вважається, що поняття «спрощених проваджень» вперше було сформульовано російським процесуалістом Ю.Ю. Грибановим, під якими він пропонув розуміти специфічну форму розгляду i вирішення спору про право, яке співвідноситься із позовною формою захисту як системою цивільних процесуальних правовідносин, в основу комплексної сутності яких покладено сукупність передумов матеріального i процесуального характеру» [8, с. 77].

На думку К. Крамер, спрощені судові процедури відрізняються від ординарного позовного провадження відсутністю або іманентною обмеженістю певних процесуальних кроків, що зумовлено необхідністю забезпечення дешевизни, оперативності та організаційної спрощеності судових процедур, в межах яких розглядаються спори незначної складності та справи із малозначним розміром позовних вимог [9, с. 139-140].

Спрощення у цивільному судочинстві Н.А. Громошина розглядає в якості певної процесуальної моделі, яка при іiі ідеальному функціонуванні порівняно 3 ординарною судовою процедурою дає змогу за меншого обсягу процесуальних дій, мінімальних фінансових затрат та оперативніше досягнути мети судочинства [10, с. 199].

Результати дослідження наукових джерел дають можливість узагальнити ідеї і погляди широкого кола вчених-процесуалістів та умовно об'єднати їх в рамках трьох основних концепцій, які висвітлюють проблему правової природи спрощених проваджень в контексті сучасної доктрини цивільного процесуального права.

У межах першої «класичної» концепції поява спрощених форм відправлення правосуддя розглядається як наслідок диференціації та подальшої симпліфікації ординарної цивільної процесуальної форми шляхом вилучення 3 неї окремих структурних компонентів: стадій, режимів, про- ваджень та/або їх певних частин. Насамперед симпліфікація покликана забезпечити адаптивність ординарної цивільної процесуальної форми до існуючих правових реалій, а тому не завжди виявляється виключно у формі вилучення зайвих, деструктивних компонентів. Зазвичай спрощення супроводжується якісною зміною архітектоніки останньої шляхом інклюзії нових, конструктивних, інноваційних процесуальних елементів.

Апологети «рестрикційного» підходу заперечують ідею диференціації ординарної цивільної процесуальної форми, яка лежить в основі та $€$ головною передумовою появи спрощених форм відправлення правосуддя і допускає спрощення лише на рівні окремих процесуальних дій. Зміст симпліфікації зводиться до законодавчо регламентованої можливості вибору альтернативних варіантів здійснення деяких процесуальних дій в рамках єдиної ординарної цивільної процесуальної форми.

«Експансіональна» передбачас поряд із передбачас поряд із загальною позовною формою захисту цивільних прав запровадження на рівні національних правових порядків екстраординарних (спрощених) форм відправлення правосуддя шляхом диференціації єдиної ординарної цивільної процесуальної форми на окремі процесуальні порядки розгляду деяких категорій цивільних справ та/або самостійні провадження чи будь-які інші форми, що мають ознаки автономних процесуальних утворень. При цьому особливістю останніх є відсутність деяких або більшості елементів ординарної цивільної процесуальної форми, притаманних загальній позовній формі захисту цивільних прав.

Поширювальне розуміння концепту «спрощення», запропоноване в межах експансіонального підходу, в сучасних умовах $€$ об'єктивно зумовленим і раціональним. Інтерпретація спрощених форм відправлення правосуддя як субсидіарних відносно 
загальної позовної форми захисту суперечить вимогам часу i не відповідає тим глобалізаційним тенденціям, що окреслилися в царині цивільного судочинства протягом останніх десятиліть.

Йдеться про альтернативні способи вирішення цивільних справ, значна частка яких (третейські суди, міжнародний комерційний арбітраж, комісії з трудових спорів (далі - КTС) є судами в розумінні абз. 1 ст. 6 ЄКПЛ (рішення Європейського суду з прав людини у справі «Компанія «Регент» проти України») [11], де розгляд цивільних спорів здійснюється за спрощеною процедурою.

Застосовуваному процесуальному порядку властива низка ознак, що визначають його як спрощений: 1) похідний характер відносно ординарної цивільної процесуальної форми, яка реалізується в межах загального позовного провадження. За своїм змістом процедура розгляду спорів у третейському суді, арбітражі чи КTC є екстраординарною модифікацією останнього; 2) доступність в аспекті абз. 1 ст. 6 ЄКПЛ, коли право ініціювати процес не обтяжене надмірними економічними та юридичними перешкодами; 3) спрощеність i прискореність судової процедури внаслідок диференціації та подальшої симпліфікації ординарної цивільної процесуальної форми шляхом виключення, інклюзії чи модифікації окремих процесуальних проваджень, стадій та/або їх структурних елементів.

Диференціація цивільної процесуальної форми стала детермінантою появи «спрощення» і його подальшої інституціоналізації, перетворивши останнє на глобальний тренд у царині цивільного судочинства. При цьому актуальною залишається проблема визначення місця спрощених форм відправлення правосуддя в системі цивільних процесуальних координат.

Пошук відповіді на це питання варто розпочати зі з'ясування змісту та специфіки природи диференціації цивільної процесуальної форми. Так, О.А. Царегородцева розглядає диференціацію крізь призму оптимізації цивільного судочинства, покликану забезпечити формування та ефективне функціонування процесуального механізму розгляду і вирішення спору про право, який би створив оптимальні передумови для максимально оперативного i ефективного досягнення цілей і вирішення завдань цивільного судочинства [12, с. 10].

Цікавою $є$ позиція 3.А. Папулової, яка під диференціацією цивільної процесуальної форми пропонує розуміти законодавчо встановлений поділ процесуального порядку розгляду i вирішення цивільних справ судом, виходячи із особливостей спірних матеріальних правовідносин, а також характеру, розміру позовних вимог і фактичних обставин справи [13, c. 14].

Залежно від ступеня повноти реалізації цивільної процесуальної форми можна виокремити загальний і спрощений порядки відправлення правосуддя у цивільних справах. 3 метою досягнення стану процесуальної економії, в умовах недоцільності застосування правил загального позовного провадження та за наявності певних обставин або ї сукупності для розгляду деяких категорій справ застосовується спрощений порядок відправлення правосуддя.

Важливою ознакою останнього $€$ високий ступінь адаптивності єдиної цивільної процесуальної форми до особливих умов, які органічно співвідносяться із правилами загального позовного провадження. В умовах здійснення спрощених форм відправлення правосуддя єдина процесуальна форма, зберігаючи органічний зв'язок із загальним позовним провадженням, яке є основою цивільного судочинства, набуває нових ознак і властивостей, зумовлених організаційною і темпоральною оптимізацією процесу розгляду і вирішення цивільної справи по суті. 
Диференціація єдиної цивільної процесуальної форми є основоположною детермінантою появи спрощених форм відправлення правосуддя. При цьому безпосереднім наслідком та зовнішньою формою вираження останніх $€$ прискорений i оптимізований процесуальний порядок розгляду та вирішення певних категорій справ, завчасно систематизованих на основі відповідних критеріїв (ціна позову, характер спірних правовідносин тощо). Диверсифікація загального позовного провадження лежить в основі спрощення як тенденції диференціації судових процедур. Спрощені форми відправлення правосуддя перебувають у системі цивільних процесуальних координат як автономні процедури, що мають похідний характер відносно класичної моделі позовного провадження.

Вирішення проблеми уніфікації доктринальних підходів до розуміння правової сутності спрощених форм відправлення правосуддя ускладнюється глибокою термінологічною диверсифікацією, коли відбувається ототожнення або заміна значень вихідного поняття змістом суміжних категорій. Крім того, результати аналізу наукових джерел дають можливість констатувати, що нині поняття «спрощених проваджень» у різних національних правопорядках i академічних традиціях охоплює коло різнорідних, диверсифікованих юрисдикційних судових процедур із високим ступенем процесуальної автентичності, що ускладнює завдання із визначення їх правової природи, розуміння змісту останніх і характеру співвідношення між собою та однотипними суміжними категоріями, такими як «прискорені» і «скорочені» провадження.

Прискорені, або «ургентні» (від англ. "urgent" - «терміновий»), провадження за своєю правовою природою та функціональним призначенням $€$ спорідненими зі спрощеними формами відправлення правосуддя i досить часто розглядаються як різновид або визначальна властивість останніх. Поява ургентних проваджень $є$ результатом еволюції ординарної цивільної процесуальної форми, що була зумовлена необхідністю забезпечення реалізації процедурних вимог права на справедливий суд, зокрема розумності строку судового розгляду; зменшенням навантаження на суддів, коли справи незначної складності, малозначні чи справи, які випливають із безспірних вимог, розглядалися у пришвидшеному порядку з мінімальними темпоральними і процесуальними затратами; оптимізації самої процедури судового розгляду шляхом подолання надмірного формалізму та скорочення темпоральних меж вчинення деяких процесуальних дій і прийняття рішень.

Повертаючись до проблеми характеру співвідношення між «спрощеними формами відправлення правосуддя» i «прискореними провадженнями», варто зазначити, що останні не $€$ наслідком диференціації ординарної цивільної процесуальної форми, а тому не передбачають їі симпліфікацію шляхом вилучення деяких структурних компонентів останньої. Таким чином, судовий розгляд відбувається в межах ординарної цивільної процесуальної форми, а темпоральний фактор набуває визначального значення, коли більшість процесуальних питань вирішується невідкладно або у скороченому порядку без будь-яких якісних модифікацій правової процедури розгляду і вирішення справи.

«Ургентність» може розглядатися як вихідна ознака та властивість спрощених проваджень. У зв'язку з цим принципово важливе значення має правова природа і шляхи досягнення такого «прискорення», яке у спрощених провадженнях є побічним наслідком диференціації та подальшої симпліфікації ординарної цивільної процесуальної форми шляхом виключення, інклюзії чи модифікації окремих процесуальних проваджень, стадій та/або їх структурних компонентів. 
Визначальним фактором тут $€$ якісна зміна структури цивільної процесуальної форми і загальної архітектоніки процедури розгляду та вирішення цивільної справи, що зумовлює i сприяє темпоральній оптимізації процесу, яка немає самостійного значення та є лише наслідком спрощення процедури.

Метою «прискорених проваджень» $€$ забезпечення невідкладного або максимально оперативного вирішення процесуальних питань, які виникають під час судового розгляду справи, але якісно не впливають на вирішення цивільного спору по суті. «Ургентність» можна інтерпретувати як особливе явище в межах цивільного судочинства, покликане забезпечити скорочення процесуальних строків розгляду деяких категорій справ незначної складності, однак воно не має ознак автономного процесуального утворення і реалізується в рамках класичної моделі судового розгляду за правилами загального позовного провадження.

Останнім часом у цивільній процесуальній доктрині поряд зі спрощеними та прискореними виокремлюються й «скорочені провадження». В академічному середовищі відсутня одностайність щодо розуміння їх правової природи, функціонального призначення та характеру співвідношення $з$ суміжними процесуальними утвореннями.

Варто зауважити, що скорочене провадження було спеціальною процесуальною формою розгляду окремих категорій адміністративних справ за Кодексом адміністративного судочинства України (далі - КАС Україн) в редакції від 07.07.2010. Чинна редакція КАС України виключає можливість розгляду адміністративних справ за правилами скороченого провадження, однак подібного роду судові процедури в межах адміністративного судочинства існують на рівні правових порядків інших держав (Боснія і Герцеговина, Греція, Туреччина, Албанія, Угорщина).
За правилами скороченого провадження суддя розглядає справу одноособово, без проведення судового засідання і виклику осіб, які беруть участь у справі, а також з обмеженою доказовою базою на підставі пояснень та інших письмових доказів, наданих сторонами.

Таким чином, скорочене провадження необхідно розглядати в якості еквівалента сумарного провадження в цивільному судочинстві, яке є особливим різновидом спрощених форм відправлення правосуддя у цивільних справах, що характеризується: 1) відсутністю судового засідання; 2) письмовим характером провадження; 3) деформалізованістю процедури; 4) скороченістю строків розгляду i вирішення спору; 5) рішення по суті справи має проміжний характер і набирає законної сили у випадку бездіяльності відповідача (боржника).

Пункт 2 ч. 2 ст. 19 Цивільного процесуального кодексу України (далі ЦПК України) закріплює диференціацію раніше єдиної позовної форми захисту цивільних прав на «загальне позовне провадження» та «спрощене позовне провадження. В контексті зазначеного вище проблемним є питання місця останнього в структурі цивільного процесу, його співвідношення із загальним позовним провадженням і яким чином диференціація єдиної позовної форми захисту цивільних прав може вплинути на зміну усталеної архітектоніки процесуальних проваджень, притаманних цивільному судочинству.

У літературі висловлюються різні судження. На нашу думку, спрощене позовне провадження має похідний від загальної позовної форми захисту характер, що не позбавляє його індивідуалізуючих ознак, властивих автономним процесуальним утворенням. Воно виникло в результаті диференціації та симпліфікації ординарної цивільної процесуальної форми шляхом експоненціального вилучення з неї цілих процесуальних стадій 
(підготовче провадження, судовий розгляд) чи їх окремих частин (етап судових дебатів), що говорить про специфічність його правової природи і автономний статус у системі цивільних процесуальних координат.

He припустимо розглядати спрощене провадження як факультативний чи субсидіарний порядок судового розгляду, оскільки законодавством чітко передбачено категоріï справ, які обов'язково підлягають розгляду (ч. 1 ст. 274 ЦПК України) та які не можуть бути розглянуті (ч. 4 ст. 274 ЦПК України) в порядку спрощеного позовного провадження.

В окремих джерелах відстоюється думка про те, що загальне позовне i спрощене провадження $€$ альтернативними, а сторони з власних міркувань самостійно обирають процесуальний порядок розгляду справи. Дійсно, ч. 2 ст. 274 ЦПК України передбачає можливість розгляду в порядку спрощеного позовного провадження будь-якої іншої справи, віднесеної до юрисдикції суду, за винятком справ, зазначених у ч. 4 ст. 274 ЦПК України, однак остаточно питання щодо призначення справи до розгляду в порядку спрощеного позовного провадження вирішується не сторонами, а $€$ дискреційним повноваженням, виключною прерогативою суду, який, приймаючи рішення, має враховувати фактори і обставини, визначені в ч. 3 ст. 274 ЦПК України, а не керуватися власним емпіричним досвідом чи суб'єктивними міркуваннями.

За своєю правовою природою спрощене позовне провадження $€$ досить специфічною процесуальною формою розгляду цивільних справ, що має низку особливостей:

- скороченість строків розгляду справи, коли суд повинен розглянути ii протягом розумного строку, але не більше шістдесяти днів із дня відкриття провадження у справі;

- вирішення питання про розгляд цивільної справи за правилами спрощеного позовного провадження належить до дискреційних повноважень суду, крім випадків, коли розгляд справи за такою процедурою прямо передбачений у законі (ч. 1 ст. 274 ЦПК України);

- відсутність підготовчого засідання;

- можливість розгляду справи без проведення судового засідання за умови малозначності позовних вимог і якщо характер спірних правовідносин і предмет доказування у справі не вимагають проведення судового засідання з повідомленням сторін для повного та всебічного встановлення обставин справи;

- судовий розгляд відбувається без повідомлення сторін за наявними у справі матеріалами, якщо відсутне клопотання будь-якої зі сторін про інше;

- суд досліджує докази і письмові пояснення, викладені у заявах по суті справи, що суттєво обмежує дію принципів змагальності та усності;

- судові дебати не проводяться.

Отже, спрощення судочинства за окремими категоріями справ $€$ основним серед сучасних трендів, які визначають вектори і динаміку розвитку цивільного процесу. Спрощені форми відправлення правосуддя покликані знайти i забезпечити баланс, оптимальне співвідношення між метою та способами ii досягнення. Результатом повинно стати вироблення максимально прийнятного i раціонального процесуального інструментарію, який має адекватно відображати досягнення сучасного етапу розвитку цивільного процесуального права і всієї системи цивільної юрисдикції, забезпечувати ефективну реалізацію принципу пропорційності та виконання завдань цивільного судочинства.

В умовах сьогодення розгляд і вирішення малозначних справ за правилами спрощеного позовного провадження є доцільним та об’єктивно зумовленим в контексті необхідності досягнення і підтримання стану 
процесуальної економіі, де спрощене провадження $€$ основним фактором оптимізації та перерозподілу процесуального навантаження на суддів і належним процесуальним інструментарієм, яким забезпечується реалізація права учасників судового процесу на справедливий судовий розгляд протягом розумного строку.

У статті досліджено спрощене провадження як прочесуальну форму розгляду малозначних справ. Встановлено, шо сучасна тендениія диференціації ицвільного судочинства, безпосереднім результатом здійснення якої є формування спрощених форм відправлення правосуддя у цивільних справах, сприяє реалізації тих завдань, які були позначені Комітетом міністрів Ради Європи в його Рекомендаціях державам-членам. Гнучкість та індивідуалізм підходів до вирішення поставлених завдань є запорукою перманентного зростання рівня ефективності та оперативності судового захисту.

Здійснено уніфікацію доктринальних підходів до розуміння змісту і правової природи спрощених форм відправлення правосуддя, а також визначено характер їх співвідношення із суміжними категоріями - «скороченими» та «прискореними» провадженнями. Автором виокремлюються класична, рестрикційна $і$ експансіональна кониелиіі розуміння правової природи спрощених проваджень у контексті сучасної доктрини ичвільного процесуального права.

Зроблено висновок, що саме в рамках останньої можливе формування органічного симбіозу наукових ідей, поглядів і підходів, який, враховуючи сучасні глобалізаційні тенденції, здатний повністю продемонструвати специфічність, трансиендентність $і$ багатогранність правової природи «спрощення» в изивільному процесі.
Обгрунтовується думка, щзо становлення $i$ подальший розвиток спрощених форм відправлення правосуддя слід пов'язувати із диференціацією циивільної процесуальної форми як базової конструкиії цивільного прочесу, яка має забезпечити ефективність правосуддя та його основну цінність - право на справедливий судовий розгляд.

На думку автора, поява спрощених проваджень є головним фактором модифікації та осучаснення ичивільної процесуальної форми, що знаходить своє відображення в диференціації, уніфікації та зміні сутнісних характеристик усталених судових проиедур. Наголошується, що питання диференціації та спрощення нерозривно пов'язані з проблемою забезпечення ефективності судової форми захисту, рівень якої залежить від ступеня впровадження нових, організаційно й темпорально оптимізованих форм відправлення правосуддя.

Ключові слова: спрощене провадження, цивільна процесуальна форма, малозначні справи, скорочені провадження, прискорені провадження.

Bilous K. Summary procedure as a procedure of disposal of small claims

The article examines summary procedure as a procedure of disposal of small claims. The current trend of differentiation of Civil Procedure, with the direct result of implementation of summary procedures in civil matters, was found to fulfill the objectives set by the Committee of Ministers of the Council of Europe in its Recommendations to Member States. Flexible and individualistic approaches to the solutions of the issue is the key to the permanent growth of the efficiency and the expeditiousness of court proceedings.

The author states that in the current context it is feasible to implement 
and gradually develop summary proceedings in order to reach and sustain the prompt disposal of legal actions. At the same time, summary proceedings are a driving factor in optimizing the conduct of a trial. They are also proper legal procedures that ensure the realization of right of fair hearing within a reasonable time for persons involved in trial proceedings. Once summary procedure for conducting civil matters came into being, they became the main factor in modifying, improving and updating the civil procedures as reflected in the differentiation, unification, and also essential changes of established legal proceedings.

It is noted that the issue of differentiation and simplification is inextricably linked with the problem of ensuring the effectiveness of the judicial protection, the level of which is proportional to the degree of introduction of new time and organization-efficient forms of legal procedures.

The author analyzed various doctrinal approaches to understanding the content and legal nature of summary procedures and unified them. Then the relationship of these approaches with related categories, such as "shortened" and "accelerated" proceedings, has been determined. The author highlights the classical, restrictive and extensive ways of understanding the legal nature of summary proceedings in the context of the modern doctrine of Civil Procedure.

Taking into account issues mentioned above, the author draws out a conclusion that extensive concept can create symbiosis of various scientific ideas, views and approaches towards the problem, that can fully reveal the specific features, transcendence and versatility of summary procedures for civil matters affected by globalization processes. Further development and implementation of summary procedures relies on Civil Procedure as the foundation for disposal of civil cases, that should provide effective litigation, along with its main principle, the right to a fair trial.

Key words: simplified proceedings, civil procedural form, minor cases, summary proceedings, expedited proceedings.

\section{Література}

1. Висновок № 6 (2004) Консультативної ради європейських суддів Ради Eвponu від 24 листопада 2004 року «Про справедливий судовий розгляд у розумні строки $і$ роль судів у судових процесах з урахуванням альтернативних способів вирішення спорів». URL: https:// court.gov.ua/userfiles / visn6_2004.pdf (дата звернення: 13.07.2020).

2. Рекомендація $R$ (81)7 Kомітету міністрів державам-иленам стосовно шляхів полегшення доступу до правосуддя, ухвалена на 68 засіданні заступників міністрів 14 травня 1981 року. URL: http: / / zakon4.rada.gov.ua/ laws/show/994_133 (дата звернення: 10.07.2020).

3. Ізарова I.O. Теоретичні засади иивільного процесу Європейського Союзу : монографія. Київ : Дакор, 2015. 335 c.

4. Storme M. Improving access to Justice in Europe. URL: http: / / wrew.pan-ol.lublin.pl / wydawnictwa/TPraw3/Storme.pdf (Jama звернення: 11.07.2020).

5. Storme M. Uniform Procedure Rules in Europe. Unity of Civil Procedural Law, Nat. Divergencies. Lublin, 1994. 306 p.

6. Ізарова I.О. Гармонізація цивільного процесуального права в європейських країнах: напрями та основні здобутки. Держава і право. 2014. № 66. С. 149-159.

7. Regulation (EC) № 861/2007 of the European Parliament and of the Council of 11 July 2007 creating a European Small Claims Procedure. URL: https: / / eur-lex.europa.eu / legal-content / EN / ALL/? uri=CELEX\%3A32007R0861 (Jama звернення: 05.07.2020).

8. Грибанов Ю.Ю. Рассмотрение дел в порядке упрощенного производства в гражданском и арбитражном процессе: сравнительное исследование правовых систем России и Германии : дисс. канд. юрид. наук. Кемерово, 2007. 235 с. 


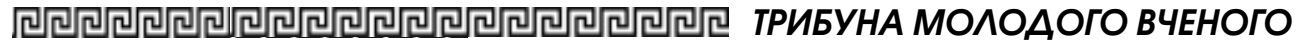

9. Kramer X. Austerity in civil Procedure and the Role of Simplified Procedures. Erasmus Law Review. 2015. № 4. P. 139-146.

10. Громошина Н.А. Дифференциация, унификация и упрощение в гражданском судопроизводстве : монография. Москва : Проспект, 2010. 264 c.

11. Рішення Європейського суду з прав людини у справі «Компанія «Регент» проти України» від 03 квітня 2008 року, заява № 773/03. URL: https:// zakon.rada.gov.ua/laws / show / 974_ 426\#Text (дата звернення: 11.07.2020).

12. Царегородиева Е.А. Способы оптимизации гражданского судопроизводства : автореф. дисс. канд. юрид. наук. Екатеринбург, 2006. 22 с.

13. Папулова 3.А. Ускоренные формы рассмотрения дел в гражданском судопроизводстве. Москва : Инфотропик Мeдua, 2014. 184 c. 